\title{
January 1993
}

\author{
Lise Harou
}

\section{Janvier 1993}

Il suffit d'une scène aperçue dans un parc depuis la fenêtre d'un autobus pour réveiller les vieilles blessures: petite histoire de la mortalité infantile.

The baby stroller in the winter path :

a carriage for winter disappearing in the fog.

Carriage or miscarriage?

The baby stroller finds its way between the trees. A concerned father I assume is pushing it through the fog.

A young woman says she doesn't want abortion for herself because it's too cruel.

One of my brothers born in the sixties was put in a coffin covered with white material instead of the carriage we all expected. It was winter time.

Sometimes it happened to be a miscarriage, sometimes the stroller, sometimes the coffin. 
January $1993 \cdot 69$

The times when the baby lived my mother would smile amongst the broidered sheets and intricate home-made baptism dress.

Making his way through the birch trees in a wet and silent park an unknown father pushes an unknown baby while flurries throw light on the scene. 